\title{
PENGARUH KEPEMILIKAN SAHAM MANAJERIAL DAN INSTITUSIONAL TERHADAP NILAI PERUSAHAAN (STUDI PERUSAHAAN NON KEUANGAN DI BURSA EFEK INDONESIA)
}

\author{
LIDYA AVINDA TAMALAGI \\ MOH. NOVAL \\ CICI RIANTY K.BIDIN \\ Program Studi S1 Manajemen, Fakultas Ekonomi, Universitas Tadulako \\ Email: Lidyaavinda@gmail.com
}

\begin{abstract}
This study aims to study Managerial and Institutional Ownership of Value of Non-Financial Companies listed on the Stock Exchange. The independent variables consist of Managerial Share Ownership (X1) and Institutional Share (X2), as well as several control variables namely Debt, Size and Age. Dependent variable is Company Value $(Y)$, using Tobins' $Q$ ratio. The research sample is 110 companies with purposive sampling sampling technique. Multiple regression data analysis process. The results showed that share ownership positively and insignificantly to the control variables. The result of managerial-related imposition on a significant corporate value of $0.368 \%$. and Institutional Share Ownership has a positive and insignificant relationship to the company with the controls, variables and companies used as control variables. The test results showed that the significant value of 0.378 .
\end{abstract}

Keywords: Managerial, Institutional, Company Value.

\begin{abstract}
ABSTRAK
Penelitian ini bertujuan untuk menganalisis pengaruh Kepemilikan Saham Manajerial dan Institusional terhadap Nilai Perusahaan Non Keuangan yang terdaftar di BEI. Variabel independen terdiri dari Kepemilikan Saham Manajerial (X1) dan Saham Institusional (X2), serta beberapa variabel kontrol yaitu Hutang, Ukuran dan Umur. Variabel dependen adalah Nilai Perusahaan (Y), diukur menggunakan rasio Tobins'Q. Sampel penelitian sebanyak 110 perusahaan ditentukan dengan tehnik penarikan sampel purposive sampling. Metode analisis data yang digunakan adalah regresi berganda. Hasil penelitian menunjukan bahwa Kepemilikan Saham Manajerial pengaruh positif dan tidak signifikan terhadap nilai perusahaan dengan mengendalikan hutang, ukuran dan umur perusahaan yang bertindak sebagai variabel kontrol. Hasil pengujian menunjukkan bahwa pengaruh kepemilikan saham manajerial terhadap nilai perusahaan memiliki nilai signifikan sebesar $0.368 \%$. dan Kepemilikan Saham Institusional memiliki pengaruh positif dan tidak signifikan terhadap nilai perusahaan dengan mengendalikan hutang, ukuran dan umur perusahaan yang bertindak sebagai variabel kontrol. Hasil pegujian menunjukan bahwa nilai signifikan sebesar 0.378 .
\end{abstract}

Kata Kunci: Manajerial, Institusional, Nilai Perusahaan

\section{PENDAHULUAN}

Tujuan perusahaan adalah untuk meningkatkan nilai yang tercermin pada pergerakan harga saham yang positif. Semakin tinggi harga saham semakin baik kinerja perusahaan. Organisasi perusahaan modern biasanya ditandai oleh pemisahan antara pemilik dan pengelola. Pemilik dinamakan prinsipal dan pengelola dinamakan agen, dalam meningkatkan nilai perusahaan pemegang saham selaku prinsipal mempercayakan pengelolaan perusahaan kepada manajer profesional selaku agen dengan harapan manajer akan bekerja semaksimal mungkin untuk meningkatkan nilai perusahaan atau mensejahterakan pemegang saham. Namun, pembagian keuntungan kerap kali menjadi pemicu terjadinya konflik antara pemegang saham dan manajer perusahaan. Manajer selalu memiliki kepentingan yang bertentangan dengan principal, dimana tunjangan jabatan dan kekuasaan menjadi penyebab utama terjadinya konflik ini bahkan hingga mengorbankan kepentingan pemegang saham. 
Tamalagi, L.A.

Atas dasar inilah Jensen dan Meckling (1976) mengemukakan theory of the firm yang menjelaskan bahwa agency problem dapat menyebabkan tidak tercapainya tujuan perusahaan, yaitu meningkatkan nilai perusahaan, karena kebijakan yang diambil oleh manajer diupayakan untuk meningkatkan kesejaterahannya terlebih dahulu kemudian meningkatkan nilai perusahaan.

Menurut Jensen dan Meckling (1976) Agency conflict dapat diminimalisir melalui kepemilikan saham oleh insider (manajer), dimana ia akan memperbaiki performance perusahaan yang dikelolanya karena kepemilikannya memberikan ia insentif moneter dan pemegang saham lain. Selanjutnya, meskipun para pemegang saham tidak dilibatkan dalam manajemen, mereka tetap dapat mengontrol manajer, sebagaimana didukung dengan penelitian yang dilakukan oleh Shleifer dan Vishny (1997) bahwa meskipun pemegang saham tidak dilibatkan dalam mengontrol manajemen, mereka tetap dapat mengendalikan manajer, oleh karena itu hipotesis memprediksi sebuah hubungan positif antara kedua variabel. Namun, pada tahun 2013 Mokhtari dan Makerani justru mengemukakan argumennya bahwa belum terdapat kejelasan mengenai hubungan antara nilai perusahaan dan kepemilikan investor institusional, meskipun kepemilikan insider memiliki pengaruh positif terhadap nilai perusahaan. Berbeda dengan penelitian yang dilakukan oleh Sugeng (2009) yang mengatakan konsentrasi kepemilikan saham di Indonesia terjadi pada porsi kepemilikan saham institusional dimana saham yang dimiliki oleh pihak institusi mencapai rata-rata $49.9 \%$ atau dapat dikatakan separuh dari total saham yang dimiliki oleh perusahaan.

Secara faktual, perusahaan di Indonesia, terutama perusahaan go public, dimiliki oleh publik, institusi dan manajemen, dimana bentuk kepemilikan cenderung terkonsentrasi pada kepemilikan saham institusional, namun terdapat kepemilikan saham manajerial dan publik. Dampak dari kepemilikan ini terhadap harga saham belum sepenuhnya jelas, misalnya, Provident Agro Tbk dengan kepemilikan saham institusional hampir 90\% memiliki harga saham Rp 456 per lembar, sebaliknya, Adaro Energy Tbk dengan kepemilikan saham institusional kurang dari 50\% memiliki harga saham yang jauh lebih tinggi, yakni Rp 1.695 per lembar.

\section{KAJIAN LITERATURE DAN PENGEMBANGAN HIPOTESIS}

\section{Nilai Perusahaan}

Nilai secara umum diidentikan dengan harga,yang diciptakan oleh perusahaan melalui kegiatan operasional. Menurut Brigham dan Erdhadt (2005:528) Nilai perusahaan adalah nilai sekarang (present value) dari free cash flow dimasa mendatang dengan tingkat diskonto sesuai biaya modal ratarata tertimbang, dalam kaitannya dengan harga saham, menurut Gitman (2006:352) nilai perusahaan adalah nilai aktual per lembar saham yang akan diterima apabila asset perusahaan tersebut dijual sesuai dengan harga saham, dengan kata lain nilai perusahaan merupakan presepsi investor terhadap perusahaan yang tercermin pada harga saham yang diperdagangkan dipasar modal.

Harga saham dan nilai perusahaan merupakan penilaian kolektif oleh investor dalam menilai seberapa baik keadaan perusahaan baik saat ini maupun prospek di masa depan, oleh karena itu tujuan dari setiap perusahaan berdasarkan theory of the firm adalah memaksimalkan kekayaan. Nilai perusahaan dalam penelitian ini diukur dengan $Q$ Tobins. Rasio ini dinilai mampu memberikan informasi paling baik, karena Q Tobin memasukan semua unsur hutang dan modal saham perusahaan, tidak hanya saham biasa dan ekuitas perusahaan. Q Tobin membandingkan nilai pasar suatu perusahaan yang terdaftar dipasar keuangan dengan nilai penggantian asset perusahaan. Jika nilai pasar hanya merefleksikan aset yang tercatat dari suatu perusahaan, Q Tobin akan sama dengan 1. Jika Q Tobin lebih besar dari 1, maka nilai pasar akan lebih besar dari nilai aset perusahaan yang tercatat. Hal ini menandakan bahwa saham overvalued. Apabila Q Tobin kurang dari 1, nilai pasarnya lebih kecil dari nilai aset perusahaan atau saham undervalued. 


\section{Kepemilikan Perusahaan}

\section{Bentuk Perusahaan dan Kepemilikan}

Kepemilikan adalah bentuk kekuasaan yang digunakan semata-mata untuk mengendalikan orang lain demi kepentingan pribadi, dalam sebuah perusahaan, kepemilikan sangat diperlukan agar perusahaan tersebut dapat dikelola demi tercapainya tujuan. Adapun bentuk-bentuk dari kepemilikan perusahaan menurut Syamsuddin (2002:19) yaitu; perusahaan perseorangan, firma, commanditaire vennotschaap $(\mathrm{CV})$, perseroan terbatas $(\mathrm{PT})$.

\section{Kepemilikan Saham Manajerial (Insider Ownership)}

Kepemilikan saham manajerial merupakan tingkat kepemilikan saham yang diukur melalui presentase jumlah saham yang dimiliki oleh pihak manajemen, yaitu direksi dan komisaris yang secara aktif berpartisipasi dalam pengambilan keputusan. Jensen (1986) mengemukakan bahwa semakin besar proporsi kepemilikan saham manajemen pada perusahaan akan dapat menyatukan kepentingan antara manajer dengan pemegang saham.

Kepemilikan saham manajerial memberi kesempatan kepada manajer untuk lebih bertanggung jawab dalam mengawasi dan melaksanakan bisnis perusahaan sekaligus memperhitungkan kebijakan deviden, apakah deviden akan dibagikan secara keseluruhan kepada pemegang saham atau digunakan untuk kemajuan perusahaan, dalam kinerjanya sebagai manajer sekaligus pemegang saham, manajer akan lebih berhati-hati dalam mengambil keputusan karena segala risiko yang akan terjadi juga berdampak pada kesejahteraan pemegang saham yang tidak lain yaitu manajer itu sendiri.

\section{Kepemilikan Saham Institusional (Institutional ownership)}

Kepemilikan saham institusional merupakan kepemilikan saham oleh institusi lain, seperti perusahaan asuransi, bank, perusahaan investasi, perusahaan institusi dan kepemilikan lain kecuali anak perusahaan dan institusi lain yang memiliki hubungan istimewa (perusahaan afiliasi dan perusahaan asosiasi). Kepemilikan saham institusi merupakan salah satu alat yang dapat mengurangi agency conflict. Barnae dan Rubin (2005) menyatakan bahwa institutional shareholders dengan kepemilikan saham yang besar, memiliki insentif untuk memantau pihak manajemen sebagai pengambil keputusan dalam perusahaan. Sejalan dengan penelitian yang dilakukan oleh Dian dan Lidyah (2014), dengan adanya kepemilikan institusional di suatu perusahaan akan mendorong peningkatkan pengawasan agar lebih optimal terhadap kinerja manajer. Jensen and Meckling (1976) menyatakan bahwa kepemilikan saham institusional memiliki peranan yang penting dalam meminimalisasi konflik keagenan yang terjadi diantara pemegang saham dengan manajer. Keberadaaan investor institusional dianggap mampu mengoptimalkan pengawasan kinerja manajemen dengan memonitoring setiap keputusan yang diambil oleh pihak manajemen selaku pengelola perusahaan.

\section{Karakteristik Perusahaan}

Hadjimanolis (2002) mengemukakan karakteristik perusahaan merupakan salah satu faktor strategi inovasi perusahaan. Demografik karakteristik dari perusahaan seperti ukuran, umur dari perusahaan dapat dipertimbangkan sebagai pengukuran struktural dan sumberdaya secara tidak langsung.

Adebiyi dan Sunday (2011) mengemukakan beberapa karakteristik perusahaan sebagai berikut:

a. Struktur Kepemilikan (Owneship Structure)

Tingkat kepemilikan direksi digunakan sebagai proxy untuk struktur kepemilkan karena tingkat kepemilikan direksi paling umum digunakan dalam literatur. Jensen dan Meckling (1976) menegaskan bahwa peningkatan kepemilikan manajerial dapat menyebabkan efek keselarasan, sehingga secara positif mempengaruhi nilai perusahaan. 


\section{b. Hutang(Debt)}

Debt merupakan salah satu variabel kontrol yang dapat digunakan untuk menguji peran disiplin dari hutang. Teori agensi memprediksi bahwa leverage yang lebih tinggi diharapkan dapat menurunkan biaya keagenan, mengurangi inefiensi dan dengan demikian mengarah pada perbaikan kinerja perusahaan, dengan adanya hutang perusahaan memperoleh tax shield yang akan menurunkan cost of capital dan meningkatkan nilai perusahaan.

c. Ukuran (Size)

Ukuran perusahaan merupakan gambaran besar kecilnya suatu perusahaan. Sudarmadji dan Sularto (2007) menyatakan besarnya ukuran perusahaan dapat dinyatakan dalam total aktiva, total penjualan dan kapitalisasi pasar. Semakin besar ukuran perusahaan, maka semakin tinggi pula tuntutan terhadap keterbukaan informasi dibandingkan dengan ukuran perusahaan yang lebih kecil, dengan mengungkapkan informasi lebih banyak, perusahaan mencoba mengisyaratkan bahwa perusahaan telah menerapkan prinsip-prinsip manajemen perusahaan dengan baik (Good Corporate Governance.

d. Umur (Age)

Umur perusahaan menunjukkan perusahaan tetap eksis, mampu bersaing dan memanfaatkan peluang bisnis dalam suatu perekonomian, dengan mengetahui umur perusahaan, maka akan diketahui pula sejauh mana perusahaan tersebut dapat survive. Semakin panjang umur perusahaan akan memberikan pengungkapan informasi keuangan yang lebih luas dibanding perusahaan lain yang umurnya lebih pendek dengan alasan perusahaan tersebut memiliki pengalaman lebih dalam mempublikasi laporan tahunan (Istanti,2009). Umur juga berdampak pada kinerja perusahaan yang akan meningkatkan nilai perusahaan oleh karena itu digunakan sebagai variabel kontrol.

\section{Kerangka Pemikiran}

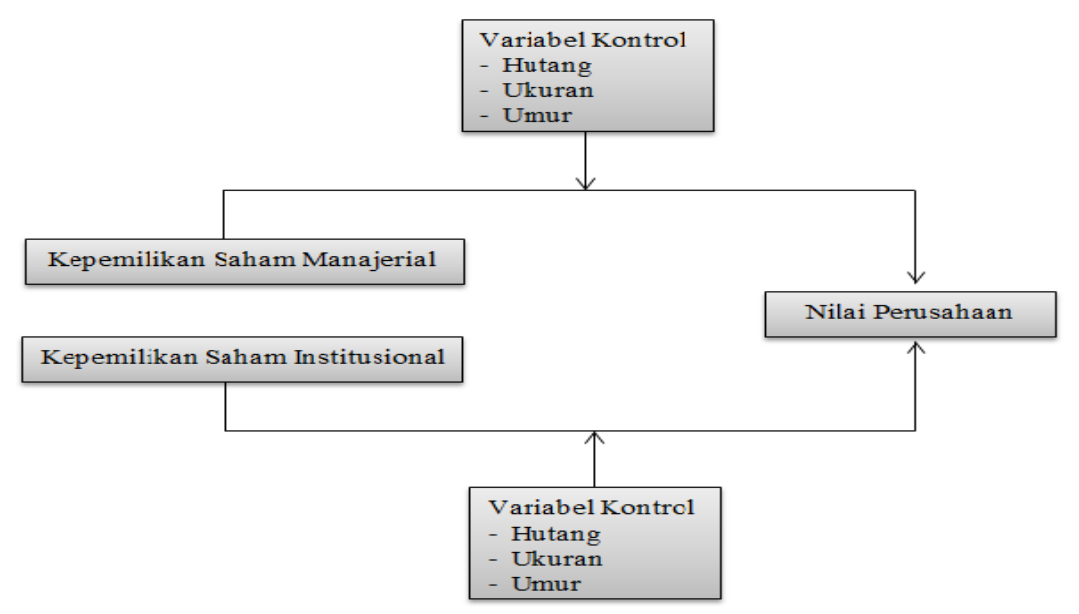

Gambar 1 Kerangka Pemikiran

H1: Diduga bahwa kepemilikan manajerial berpengaruh positif dan signifikan terhadap nilai perusahaan, dengan hutang, ukuran dan umur perusahaan sebagai variabel kontrol.

H2: Diduga bahwa kepemilikan institusional berpengaruh positif dan signifikan terhadap nilai perusahaan, dengan hutang, ukuran dan umur perusahaan sebagai variabel kontrol.

\section{METODE PENELITIAN}

Penelitian yang dilakukan adalah sebuah penelitian deskriptif-verifikatif. Menurut Sugiyono (2013:206), verifikatif adalah jenis penelitian yang memiliki tujuan untuk menguji suatu teori atau hasil penelitian sebelumnya, sehingga diperoleh hasil yang memperkuat atau menggugurkan teori atau hasil penelitian sebelumnya. Penelitian Deskriptif adalah suatu penelitian yang dilakukan dengan 
tujuan utama untuk memberikan gambaran atau deskripsi tentang suatu keadaan secara objektif. Pengumpulan data dari penelitian ini dilakukan dengan cara telaah dokumen-dokumen yang tersedia pada situs Bursa Efek Indonesia. Publikasi dokumen yang memuat data dan informasi yang dibutuhkan untuk penelitian ini selanjutnya dikumpulkan dengan cara browsing internet. Teknik pengambilan sampel menggunakan metode purposive sampling yaitu pengambilan sampel yang menggunakan pertimbangan-pertimbangan atau kriteria tertentu. Adapun kriteria-kriteria yang digunakan dalam penentuan sampel untuk penelitian ini adalah sebagai berikut:

1. Perusahaan berada dalam sektor non-keuangan.

2. Perusahaan non-keuangan yang mempublikasikan laporan keuangan konsolidasi tahun buku 2016.

3. Memiliki kelengkapan informasi sesuai dengan variabel-variabel yang dibutuhkan untuk penelitian ini.

Berdasarkan tiga kriteria tersebut, proses pemilihan sampel penelitian ini dapat dilihat berikut:

Tabel 1 Perhitungan Sampel Penelitian

\begin{tabular}{|l|c|}
\hline \multicolumn{1}{|c|}{ Kriteria Sampel } & Jumlah Sampel \\
\hline Jumlah Populasi Perusahaan Non Keuangan & 456 Perusahaan \\
\hline $\begin{array}{l}\text { Perusahaan yang tidak memiliki kelengkapan } \\
\text { informasi selama periode penelitian }\end{array}$ & (346) Perusahaan \\
\hline $\begin{array}{l}\text { Perusahaan yang memiliki kelengkapan informasi } \\
\text { keuangan selama periode penelitian }\end{array}$ & 110 Perusahaan \\
\hline
\end{tabular}

\section{Alat Analisis}

Hubungan antar variabel dalam penelitian ini digambarkan sebagai sebuah keterkaitan fungsional berbentuk regresi berganda. Analisis regresi berganda digunakan untuk menganalisis pengaruh antara variabel independen dan variabel dependen, dalam penelitian ini juga digunakan variabel kontrol. Adapun model regresi berganda di formulasikan sebagai berikut:

Dimana:

DR

SIZE

AGE

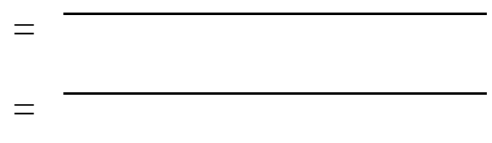

$=$

$=$ Natural logarithm of total assets

$=$ Natural logarithm of number of years since inception of the firm to the observation date.

Koefisien model diestimasi dengan menggunakan OLS (Ordinary Least Square). Analisis terhadap hasil-hasil model dilakukan dengan melihat goodness of fits (R dan F) dan statistik $\mathrm{t}$ (Uji Parsial). 


\section{HASIL DAN PEMBAHASAN}

\section{Tabel 2 Hasil Uji Regresi}

\begin{tabular}{|c|c|c|c|c|c|c|c|c|c|c|}
\hline No & Regresi & Const & X1 & X2 & VK1 & VK2 & VK3 & $\begin{array}{c}\mathrm{R} \\
\text { Square }\end{array}$ & $\mathrm{F}$ & $\mathrm{N}$ \\
\hline 1 & Regresi 1 & 1.374 & -0.532 & & & & & 0.003 & 0.283 & 110 \\
& & $(0.000)$ & $(0.596)$ & & & & & & & \\
\hline 2 & Regresi 2 & 0.920 & 0.293 & 0.988 & & & & 0.012 & 0.629 & 110 \\
& & $(0.056)$ & $(0.770)$ & $(0.325)$ & & & & & & \\
\hline 3 & Regresi 3 & 0.270 & 1.291 & 0.637 & 8.093 & & & 0.389 & 22.505 & 110 \\
& & $(0.484)$ & $(0.199)$ & $(0.221)$ & $(0.000)$ & & & & & \\
\hline 4 & Regresi 4 & 2.160 & 0.914 & 0.893 & 7.851 & -1.461 & & 0.401 & 17.593 & 110 \\
& & $(0.112)$ & $(0.363)$ & $(0.374)$ & $(0.000)$ & $(0.147)$ & & & & \\
\hline 5 & Regresi 5 & 2.152 & 0.904 & 0.885 & 7.812 & -1.455 & 0.056 & 0.401 & 13.941 & 110 \\
& & $(0.117)$ & $(0.368)$ & $(0.378)$ & $(0.000)$ & $(0.149)$ & $(0.955)$ & & & \\
\hline
\end{tabular}

Sumber: Data diolah Maret 2018

Tabel 2 memperlihatkan bahwa data yang mewakili variabel dependen dan independen dari 110 perusahaan yang menjadi objek penelitian diuji dalam bentuk analisis regresi berganda. Berdasarkan hasil uji regresi 1, nilai statistik $\mathrm{R}^{2}$ sebesar 0,003 dan $\mathrm{F}$ tidak signifikan, variabel kepemilikan saham manajerial menunjukkan hubungan yang negatif dan tidak signifikan terhadap nilai perusahaan.

Integrasi kepemilikan saham manajerial dan kepemilikan saham institusional dalam regresi 2 menghasilkan nilai statistik $\mathrm{R}^{2}$ sebesar 0.012 dan statistik $\mathrm{F}$ menunjukkan nilai positif dan tidak signifikan. Koefisien X1 dan X2 bernilai positif dan tidak signifikan. Perubahan nilai koefisien X1 pada regresi kedua setelah di integrasikan koefisien X2 menunjukkan hasil yang positif, artinya bahwa adanya kepemilikan saham oleh pihak institusi berdampak pada peningkatan nilai saham manajemen melalui pengawasan oleh pihak intitusi yang mendorong kinerja manajemen. Pendapat tersebut merujuk pada Dian dan Lidyah (2014) bahwa dengan adanya kepemilikan intitusional di suatu perusahaan akan mendorong peningkatan pengawasan agar lebih optimal terhadap kinerja manejer.

Pada pengujian regresi 3, dengan mengintegrasikan hutang sebagai variabel kontrol, nilai Statistik $\mathrm{R}^{2}$ sebesar 0,389 dan statistik $\mathrm{F}$ menunjukkan nilai positif dan signifikan. Integrasi variabel hutang (sebagai variabel kontrol) dalam regresi meningkatkan nilai signifikansi dari variabel X1 dan X2. Yang artinya bahwa jumlah hutang yang meningkat mendorong perusahaan untuk dapat mengurangi pemborosan, mengurangi inefiensi yang mengarah pada perbaikan kinerja perusahaan. Pendapat tersebut didukung oleh Jensen (1986) bahwa dengan adanya hutang yang tinggi dapat digunakan untuk mengurangi free cash flow yang berlebihan atau menghidari investasi yang sia-sia yang pada akhirnya berdampak terhadap nilai perusahaan.

Regresi 4 memperlihatkan nilai statistik $\mathrm{R}^{2}$ sebesar 0.401 dan statistik $\mathrm{F}$ yang signifikan. Integrasi variabel hutang dan ukuran perusahaan (sebagai variabel kontrol) meningkatkan tingkat signifikansi variabel X1 dan X2 walaupun secara statistik belum signifikan, dengan kata lain faktor hutang dan ukuran perusahaan relatif mendukung efektivitas manajerial dan kontrol institusi dalam pengelolaan perusahaan. Namun hasil regresi menunjukan ukuran perusahaan berpengaruh negatif dan tidak signifikan yang berarti bahwa semakin besar ukuran perusahaan akan mempengaruhi citra perusahaan tersebut. Hasil ini sejalan dengan penelitian yang dilakukan oleh Desemlianty (2003) yang mengatakan bahwa ukuran perusahaan yang tinggi akan membuat pihak manajer lebih leluasa untuk menggunakan aset perusahaan.

Berdasarkan pengujian pada regresi 5 , dengan mengintegrasikan umur perusahaan sebagai variabel kontrol, diperoleh Statistik $\mathrm{R}^{2}$ sebesar 0.401 atau tidak berbeda dengan hasil pengujian pada regresi 4 . Artinya bahwa dengan mengintegrasikan umur perusahaan sebagai variabel kontrol pada regresi tidak 
mengubah besaran pengaruh variabel kepemilikan saham manajerial dan kepemilikan saham institusional terhadap nilai perusahaan. Statistik t menunjukkan koefisien X1 dan X2 berpengaruh positif dan tidak signifikan.

Hasil uji regresi tersebut maka variabel kepemilikan saham manajerial dan kepemilikan saham institusional berpengaruh positif dan tidak signifikan terhadap nilai perusahaan, dengan mengendalikan hutang, ukuran dan umur perusahaan sebagai variabel kontrol. Sehingga hubungan antara koefisien X1 dan X2 terhadap variabel dependen tidak dipengaruhi oleh faktor lain yang tidak diteliti.Untuk lebih jelasnya bentuk persamaan dari regresi 5 dijabarkan sebagai berikut:

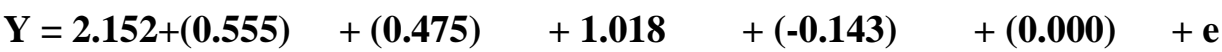

Berdasarkan hasil penjabaran di atas maka hasil persamaan regresi berganda dapat disimpulkan sebagai berikut:

1. Nilai Konstanta sebesar 2.152, memiliki arti bahwa jika variabel (Kepemilikan Saham Manajerial dan Kepemilikan Saham Institusional) bernilai 0, maka variabel dependen (Nilai Perusahaan Non Keuangan) memiliki nilai sebesar 2.152.

2. Koefisien regresi Kepemilikan Saham Manajerial $\left(\mathrm{X}_{1}\right)$ sebesar 0.555 , memiliki arti bahwa jika nilai variabel lainya tetap, maka setiap peningkatan Kepemilikan Saham Manajerial sebesar 1, akan meningkatkan nilai perusahaan sebesar 0.555 dengan mengendalikan hutang, ukuran dan umur perusahaan sebesar nilai konstantanya masing-masing.

3. Koefisien regresi Kepemilikan Saham Institusional $\left(\mathrm{X}_{2}\right)$ sebesar 0.475 , yang berarti bahwa jika variabel independen lainnya tetap, maka setiap peningkatan Kepemilikan Saham Institusional sebesar 1, akan meningkatkan nilai perusahaan sebesar 0.475 dengan mengendalikan hutang, ukuran dan umur perusahaan sebesar nilai konstantanya masing-masing.

\section{Pengujian Hipotesis}

\section{a) Hipotesis 1}

Kepemilikan manajerial berpengaruh positif terhadap nilai perusahaan dengan hutang, ukuran dan umur perusahaan sebagai variabel kontrol

Regresi 1 menghasilkan koefisien kepemilikan manajerial negatif sedangkan regresi 2 sampai dengan 5 menghasilkan koefisien kepemilikan manajerial positif. Seluruh koefisien tidak signifikan. Seluruh variabel kontrol memiliki koefisien sebagaimana yang diprediksi oleh teori. Berdasarkan hasil-hasil regresi ini, variabel kepemilikan manajerial tidak berpengaruh signifikan terhadap nilai perusahaan, sehingga hipotesis 1 ditolak.

\section{b) Hipotesis 2}

\section{Kepemilikan institusional berpengaruh positif terhadap nilai perusahaan dengan} hutang, ukuran dan umur perusahaan sebagai variabel kontrol

Regresi 2 sampai dengan 5 menghasilkan koefisien kepemilikan institusional positif dan tidak signifikan, atau variabel kepemilikan institusional tidak berpengaruh terhadap nilai perusahaan. Seluruh variabel kontrol memiliki koefisien sebagaimana yang diprediksi oleh teori. Berdasarkan hasil-hasil regresi ini, variabel kepemilikan institusional tidak berpengaruh signifikan terhadap nilai perusahaan, sehingga hipotesis 2 ditolak.

\section{Pembahasan}

\section{a.Pengaruh Kepemilikan Saham Manajerial}

Variabel kepemilikan saham manajerial memiliki pengaruh positif dan tidak signifikan terhadap nilai perusahaan non keuangan yang terdaftar di BEI tahun 2016, dengan hutang, ukuran dan umur perusahaan sebagai variabel kontrol. Fakta ini dapat dikaitkan dengan kepemilikan saham manajerial yang relatif kecil. Rendahnya tingkat kepemilikan saham oleh manajemen berdampak terhadap 
Tamalagi, L.A.

perilaku manajemen yang lebih mengutamakan kepentingan pribadinya sebagai seorang manajer dari pada kepentingan pemegang saham.

Hasil penelitian ini medukung teori Jensen (1986) yang menyatakan bahwa semakin besar proporsi kepemilikan saham manajemen pada perusahaan akan dapat menyatukan kepentingan antara manajer dan pemegang saham. Persentase kepemilikan saham yang tinggi oleh manejer akan mendorong peningkatan kinerja manejer dan lebih berhati-hati dalam mengambil keputusan karena segala risiko yang terjadi juga berdampak pada manejer itu sendiri, yang akan mendorong peningkatan nilai perusahaan. Selanjutnya Wicaksono (2002:15) menyatakan bahwa semakin tinggi kepemilikan saham manajerial akan menyebabkan pemegam saham eksternal seperti pihak institusi akan sulit untuk memantau tindakan manajer dalam perusahaan, oleh karena itu memperbaiki kinerja perusahaan juga dilakukan dengan meningkatkan kepemilikan saham intitusional, dengan demikian, maka jelas bahwa peningkatan kepemilikan saham manajerial dapat memberikan kontribusi terhadap peningkatan nilai perusahaan.

Hasil penelitian ini sejalan dengan penelitian yang dilakukan oleh Sukirni (2012) bahwa kepemilikan saham yang rendah oleh pihak manajemen mengakibatkan manajer lebih mengutamakan kesejahteraannya terlebih dahulu kemudian kesejaterahan perusahaan. Namun, berbeda dengan penelitian yang dilakukan oleh Welim dan Rusiti (2013) bahwa kepemilikan saham yang signifikan oleh manajer menandakan bahwa manajer memiliki status ganda yaitu sebagai pemilik dan pengelola perusahaan. Sebagai pengelola perusahaan manajer juga dapat bertindak untuk memutuskan segala sesuatu yang berkaitan dengan perusahaan. Peran status ganda ini membuat manajer seolah-olah mengawasi dirinya sendiri, sehingga memudahkan manajer mencapai kepentingan pribadinya bukan kepentingan perusahaan.

Sedangkan variabel kontrol menunjukkan bahwa hutang berpengaruh positif dan signifikan terhadap nilai perusahaan, artinya bahwa jumlah hutang yang meningkat mendorong perusahaan untuk mengurangi pemborosan, mengurangi inefisiensi yang mengarah pada perbaikan kinerja perusahaan. Ukuran perusahaan menunjukkan nilai koefisien sebesar -0.142 dan nilai signifikansi sebesar 0.149 , artinya ukuran perusahaan berpengaruh negatif terhadap nilai perusahaan dengan kata lain bahwa ukuran perusahaan tidak dapat memberikan kontribusi dalam meningkatkan nilai perusahaan dimana semakin meningkatnya ukuran suatu perusahaan akan memberikan kesempatan kepada pihak manajer untuk lebih leluasa menggunakan aset perusahaan. Umur perusahaan berpengaruh positif dan tidak signifikan terhadap nilai perusahaan yang ditunjukkan dengan nilai signifikan sebesar 0.955 , artinya bahwa perusahaan yang lama berdiri tetap menunjukkan exsistensinya atau kemampuannya untuk bertahan dalam persaingan sehingga menarik minat investor dan dapat meningkatkan nilai perusahaan. Hasil pengujian tersebut dapat dinyatakan bahwa peningkatan kepemilikan saham manajerial dapat mendorong peningkatan nilai perusahaan dengan mengendalikan hutang, ukuran dan umur perusahaan. Adapun variabel kontrol ini berperan untuk menetralkan atau mengendalikan hubungan antara kepemilikan saham manajerial terhadap nilai perusahaan, sehingga hubungan tersebut tidak dipengaruhi oleh faktor luar yang tidak diteliti dalam penelitian ini.

\section{b. Pengaruh Kepemilikan Saham Intitusional}

Hasil regresi menunjukan bahwa kepemilikan saham institusional memiliki pengaruh positif dan tidak signifikan terhadap nilai perusahaan, dengan mengendalikan hutang, ukuran dan umur perusahaan yang bertindak sebagai variabel kontrol. Berdasarkan hasil ini, hipotesis kepemilikan institusional ditolak. Hasil pengujian ini tidak sejalan dengan penelitian Apriada dan Suardika (2016) bahwa kepemilikan saham istitusional berhubungan positif terhadap nilai perusahaan.

Jika volume saham yang dimiliki oleh pihak institusi cukup besar, pihak institusi akan merasa memiliki wewenang untuk memberi pengawasan kepada pihak manajer agar lebih berhati-hati dalam menjalankan perusahaan yang berdampak pada peningkatan nilai perusahaan. Sehingga dapat 
dikatakan bahwa tingkat kepemilikan saham intitusional yang tinggi akan meningkatkan nilai perusahaan. Pendapat tersebut merujuk pada penelitian Barnae dan Rubin (2005) yang menyatakan bahwa kepemilikan saham intitusional yang besar dapat memantau pihak manajemen sebagai pengambil keputusan dalam perusahaan yang akan mengarah pada peningkatan kinerja manajemen.

Hasil penelitian mendukung teori Jansen and Meckling (1976) yang menyatakan bahwa kepemilikan saham institusional memiliki peranan yang penting dalam meminimalisasi konflik keagenan yang terjadi diantara pemegang saham dengan manajer. Keberadaaan investor institusional dianggap mampu mengoptimalkan pengawasan kinerja manajemen dengan memonitoring setiap keputusan yang diambil oleh pihak manajemen selaku pengelola perusahaan yang mengarah pada peningkatan nilai perusahaan.

Penelitian ini sejalan dengan peneltian yang dilakukan oleh Sukirni (2012) dimana dalam penelitiannya semakin besar kepemilikan saham oleh pihak institusi maka semakin efisien pemanfaatan aktiva perusahaan dan diharapkan juga dapat bertindak sebagai pencegahan terhadap manipulasi laba yang dilakukan oleh pihak manajemen sehingga dapat meningkatkan nilai perusahaan, dalam penelitian Wida dan Suartana (2014), hasil uji statistik menunjukan bahwa peningkatan kepemilikan saham institusional membawa dampak pada kuatnya tingkat pengendalian yang dilakukan oleh pihak pemegang saham atas perilaku manajer yang ditujukan untuk mengurangi agency cost dan meningkatkan nilai perusahaan.

Berdasarkan uraian tersebut dapat dinyatakan bahwa kepemilikan saham intitusional yang besar dapat meningkatkan nilai perusahaan dengan mengendalikan hutang, ukuran dan umur perusahaan. Hutang, ukuran dan umur perusahaan yang bertindak sebagai variabel kontrol ini mempunyai fungsi untuk menyamakan faktor yang mempengaruhi hubungan antara kepemilikan saham manajerial dan kepemilikan saham institusional terhadap nilai perusahaan dengan tujuan untuk mengeliminasi faktor luar yang tidak diteliti dan mendapatkan hasil pengujian yang lebih pasti.

\section{KESIMPULAN DAN SARAN}

\section{Kesimpulan}

1. Hasil penelitian menjelaskan bahwa variabel kepemilikan saham manajerial memiliki pengaruh positif dan tidak signifikan terhadap nilai perusahaan dengan hutang, ukuran dan umur perusahaan sebagai variabel kontrol.

2. Hasil penelitian menjelaskan bahwa variabel kepemilikan saham institusional memiliki pengaruh positif dan tidak signifikan terhadap nilai perusahaan dengan hutang, ukuran dan umur perusahaan sebagai variabel kontrol.

\section{Saran}

1. Bagi Investor yang ingin melakukan investasi, sebaiknya terlebih dahulu melakukan pengamatan terhadap informasi yang telah dipublikasi oleh perusahaan yang akan dijadikan pedoman dalam mengambil keputusan untuk berinvestasi, dalam hal ini investor perlu memperhatikan perkembangan harga saham dan pembagian saham untuk pihak investor dan pihak manajemen perusahaan dari tahun ke tahun, sehingga dapat dikatakan bahwa perusahaan tersebut memiliki prospek yang baik kedepan dan layak dijadikan tempat berinvestasi.

2. Bagi peneliti selanjutnya, penelitian ini diharapkan dapat menjadi acuan bagi peneliti yang berkaitan dengan struktur kepemilikan saham dan nilai perusahaan dengan menambah periode penelitian, mengganti objek penelitian pada sektor atau indeks tertentu dan menambah variabel dalam penelitian.

3. Bagi perusahaan, khususnya perusahaan-perusahaan yang ada di Indonesia ada baiknya lebih memperhatikan status kepemilikan saham oleh pihak institusi maupun pihak manajemen agar 
Tamalagi, L.A.

saham yang dimiliki menjadi acuan bagi pemegang saham untuk terus memperhatikan statusnya sebagai pemegang saham dan dapat meningkatkan nilai perusahaan.

\section{REFERENSI}

Adebiyi J, dan Sunday O,2011. Ownership Structure and Firm Performance : Evidence From Nigerian Listed Companies. Corporate Ownership \& Control, Volume 8, Issue 4.

Apriada, dan Suardhika,2016. Pengaruh Struktur Kepemilikan Saham, Struktur modal dan profitabilitas pada Nilai Perusahaan. E-Jurnal Ekonomi dan Bisnis Universitas UdayanaVolume 5.2, Pages 201-218.

Bambang, Sugeng. 2009. Pengaruh Struktur Kepemilikan dan Struktur Modal Terhadap Kebijakan Instansi Deviden di Indonesia.Jurnal Ekonomi Bisnis. Nomor 1, Pages 37-48

Barnae Amir dan Amir Rubin, 2005. "Corporate Social Responsibility as a Conflict Between Shareholders". Jurnal Keuangan dan Perbankan. Vol.16, No 2

Brigham, E.F., Ehrhardt, M.C. (2005), Financial Management Theory And Practice, Eleventh Edition, South Western Cengage Learning, Ohio.

Desemlianty.2003.Analisa Terhadap Faktor yang Menentukan Nilai Perusahaan: tinjauan terhadap Agency Theory. Skripsi Strata Satu. Universitas Atmajaya, Jakarta

Dian dan Lidya. 2014. Pengaruh corporate social Resposibility,Kepemeilikan Manajerial dan Kepemilikan Institusional Terhadap Nilai Perusahaan Tambang Batu Bara yang Terdaftar di BEI. Journal STIE MBP

Dwi Sukirni.2012. Kepemilikan Manajerial,Kepemilikan Institusional, Kebijakan Dividend an Kebijakan Hutang Analisis terhadap Nilai Perusahaan.Acounting Analysis Journal.

Gitman, Lawrence J. 2006.Principles of Managerial Finance, seventeenth edition. Massachusetts: Addison-Wesley Publishing Company.

Hadjimanolis, Athanasios, 2000, "An Investigation of Innovation Antecedents in Small Firms in the Istanti, Sri Layla Wahyu. 2009. Faktor-Faktor Yang Mempengaruhi Pengungkapan Sukarela Modal Intelektual. Tesis. Program Pasca Sarjana. Universitas Diponegoro. Semarang.

Jensen, C Michael. 1986. Agency Cost of Free cash Flow, Corporate Finance, and Takeovers, American Economic Review 76 (2), 323-329.

Jensen dan Meckling.1976.Theory Of The Firm: Managerial Behavior, Agency Costs and Ownership Structure. Journal Of Financial Economics, Volume 3,No.4 PP 305-360.

Jensen, C Michael. 1986. Agency Cost at Free Cash Flow Corporate Finance and Takeover. American Economic Review. Vol 76 No 2 PP 323-329.

Mokhtari, and Makerani,2013. Relationship of Institusional Ownership with Firm Value and Earning Quality : Evidence from Tehran Stock Exchange. Internasional Journal of Economy, Management and Social Sciences, Volume 2(7), Pages : 495-502.

Rusiti dan Welim.2013.Pengaruh Kepemilikan Manajerial dan Kepemilikan Institusional Terhadap Nilai Perusahaan.(Studdi empiris pada perusahaan Perbankan yang terdaftar di BEI).

Shleifer, Andrei and Vishny, W Robert. 1997. A Survey Of Corporate Governance. The Journal Of Finance. Vol LII No 2.

Sugiyono.2013. Metode Penelitian Bisnis. Alfabeta.Bandung

Syamsudin, Lukman.2002. Manajemen Keuangan Perusahaan.PT RajaGrafindo Persada, Jakarta

Wicaksono, Adhi Anjar.2002. Pengaruh Struktur Kepemilikan Manajerial dan Publik,Ukuran perusahaan, Ebit/Sales dan Total Hutang/Total Asset Terhadap Nilai Perusahaan yang telah Go Public dan telah tercatat di Bursa Efek Indonesia. Tesis UNDIP

Wida P.D, Ni Putu and Suartana, I Wayan.2014. Pengaruh Kepemilikan Manajerial dan Kepemilikan Institusional Pada Nilai Perusahaan.E-Jurnal Akuntansi Universitas Udayana, Volume 9.3,Pages 575-590. 